\title{
INOVASI KEMASAN DAN PELUASAN PEMASARAN PRODUK CINCAU HIJAU KTHR AMANAH
}

\author{
Happy Febrina Hariyani, Firdha Aksari Anindyntha
}

Fakultas Ekonomi dan Bisnis, Universitas Muhammadiyah Malang

happyfebrina@umm.ac.id

\begin{abstract}
Innovation and marketing of a product are prioritized for the progress of a business. KTHR Rukun Amanah produces a product, namely a drink from processed green grass jelly, which is one of the advantages of increasing people's income. However, there are problems faced by KTHR in developing processed green grass jelly products are the limited marketing of the product, which includes unattractive product packaging and low selling prices. Increase sales and consumer interest in green grass jelly processed drinks; innovation and marketing expansion are needed. The form of creation carried out here is designing the brand logo for processing green grass jelly and packaging innovation in bottles to make it more attractive. Furthermore, marketing expansion is carried out by providing access to sell Chao Chendol beverage products to bazaars and stalls in the University of Muhammadiyah Malang.
\end{abstract}

Keywords: green grass jelly, innovation, marketing.

\begin{abstract}
Abstrak
Inovasi dan pemasaran suatu produk menjadi hal yang diutamakan untuk kemajuan suatu usaha. KTHR Rukun Amanah menghasilkan suatu produk yaitu minuman dari olahan cincau hijau yang menjadi salah satu keunggulan dengan harapan dapat meningkatkan pendapatan masyarakat. Namun terdapat permasalahan yang dihadapi KTHR dalam mengembangkan produk olahan cincau hijau adalah terbatasnya pemasaran produk yang meliputi kemasan produk kurang menarik dan harga jual rendah. Untuk meningkatkan penjualan dan minat konsumen terhadap minuman olahan cincau hijau, maka diperlukan inovasi dan peluasan pemasaran. Bentuk inovasi yang dilakukan di sini adalah desain logo merek untuk olahan cincau hijau dan inovasi kemasan dalam bentuk botol supaya lebih menarik. Selanjutnya untuk peluasan pemasaran dilakukan dengan memberi akses untuk menjual produk minuman Chao Chendol ke bazaar dan juga lapak yang ada di lingkungan kampus Universitas Muhammadiyah Malang
\end{abstract}

Kata kunci: cincau hijau, inovasi, pemasaran

MARTABE : Jurnal Pengabdian Masyarakat | 227 


\section{PENDAHULUAN}

Daun cincau hijau (Premna oblongifolia Merr) merupakan salah satu tanaman rambat yang banyak tumbuh di Asia Tenggara. Di Indonesia, tanaman ini dimanfaatkan dan diolah menjadi minuman yang menyegarkan. Cincau hijau digemari karena daunnya yang tipis dan lemas sehingga lebih mudah dibentuk menjadi gelatin ataupun agar-agar (Nurlela, 2015). Kandungan dan manfaat tanaman cincau hijau dipercaya dapat bermanfaat bagi Kesehatan karena mengandung senyawa yang dibutuhkan oleh tubuh. Daun cincau mengandung serat pektin dak aktivitas antioksidan yang sangat tinggi (Nurdin et al., 2009). Siregar \& Miladiyah (2011) menambahkan bahwa daun cincau memliki aktivitas anti raang lambung. Tanaman cincau juga kaya akan zat aktif flavonoid dan alkaloid. Yang berperan sepagai antihepatotoksi, anti HIV 1, anti tumor, anti-inflamasi dan melindungi fungsi jantung (Lokesh \& Amitsankar, 2012).

Olahan cincau hijau menjadi salah satu keunggulan di Kelompok Tani Hutan Rakyat (KTHR) Rukun Amanah, Desa Sukodadi, Kecamatan Wagir, Kabupaten Malang. Banyaknya tanaman cincau hijau yang tumbuh di areal sekitar KTHR membuat warga, terutama anggota kelompok KTHR memanfaatkannya menjadi olahan minuman. Tanaman cincau hijau dapat ditemukan di hamper seluruh kebun di rumah warga karena tanaman ini tumbuh secara liar. Menurut ketua KTHR Rukun Amanah, cincau hijau olahan KTHR Amanah banyak diminati oleh masyarakat di sekitar Malanng Raya karena kualitasnya yang lebih bagus dari pada produk cincau hijau di daerah lain. Cincau hijau KTHR Rukun Amanah juga telah mensuplai salah satu gerai minuman di daerah Malang.
Permasalahan utama yang dihadapi oleh KTHR Rukun Amanah dalam mengembangkan produk olahan cincau hijau adalah terbatasnya pemasaran produk cincau hijau. Keterbatasan ini meliputi kurang menariknya kemasan produk minuman cincau hijau sehingga konsumen tidak banyak tertarik dengan produk tersebut. Selain itu, harga jual yang rendah dimana produk yang olahan agar-agar cincau hijau yang dijual untuk mensuplai gerai minuman menjadikan harga jual cincau hijau olahan, menjadi sangat murah. Belum adanya akses untuk dapat menjual agar-agar cincau hijau ke supermarket-supermarket sekitar Malang Raya agar dapat meningkatkan produksi serta nilai jual di pasar. Inovasi untuk meningkatkan produksi dan pemasaran menjadi hal yang penting demi kemajuan suatu usaha (Arifudin et al., 2020). Menurut (Khamidah, 2005), keberhasilan suatu produk akan bermuara pada kinerja pemasarannya. Hal itulah yang akan menjadi pertimbangan konsumen apakah produk tersebut mempunyai keunggulan dibandingkan produk sejenis dari pesaing.

Perkembangan teknologi yang begitu pesat menuntut produsen harus selalu berinovasi. Semakin banyak pesaing dalam bisnis yang menyebabkan semakin banyaknya pilihan bagi konsumen. Untuk itu, produsen harus pandai menangkap minat dan selera konsumen yang sedang banyak diminati. Keunikan produk sebagai hasil inovasi secara temporer akan membawa persaingan yang lebih besar (McDaniel, 2002). (Hasan, 2013) menambahkan bahwa keunggulan bersaing suatu usaha akan mampu bertahan sehingga akan mendukun kinerja pemasaran dari suatu usaha. (Kotler, 2012) mendefinisikan inovasi produk sebagai gabungan dari berbagai 
Happy Febrina Hariyani,dkk. Inovasi Kemasan Dan Peluasan Pemasaran Produk ...

macam proses yang saling mempenaruhi antara satu dengan lainnya.

Selain inovasi, pemasaran merupakan salah satu aspek yang sangat penting dalam keberhasilan suatu usaha. Teknik dan strategi pemsaran yang tepat akan membawa produsen kepada pasar yang tepat sasaran dan efiesien. Tujuan pemasaran sendiri adalah memberikan pengaruh pada konsumen agar bersedia membeli produk (Widayati \& Rahman, 2019). Tambajong (2013) mendefinisikan pemasaran sebagai suatu sistem dari kegiatan bisnis yang dirancang untuk merencanakan, menentukan harga, mempromosikan dan mendistribusikan produsk yang dapat memuaskan keinginan dalam mencapai tujuan perusahaan. Sejalan dengan pernyataan tersebut, (Kotler, 2012) menambahkan bahwa pemasaran merupakan proses menciptakan nilai bagi pelanggan dan membangun hubungan pelanggan yang kuat.

Pemilihan pasar yang tepat untuk pemasaran juga menjadi hal yang utama. (Amaya \& Alwang, 2011) menyatakan bahwa pemilihan pasar ditentukan oleh kuantitas produk yang dihasilkan, jarak pasar, tingkat jalan beraspal, biaya transportasi, harga yang diharapkan, persyaratan kualitas, akses informasi, dan kondisi pengelolaan pasar.

Sebagai upaya dalam memecahkan permasalahan industri olahan Cincau Hijau di KTHR Rukun Amanah, Desa Sukodadi, Kecamatan Wagir, Kabupaten Malang, dibutuhkan inovasi berupa pembaharuan kemasan dan perluasan pemasaran usaha olahan Cincau Hijau di area Malang Raya. Tujuan adalah agar KTHR dapat mengembangkan produk dan pemasarannya di tengah berjamurnya industri minuman.

\section{METODE}

Metode dalam pelaksanaan program pengabdian masyarakat dalam mendampingi industri olahan cincau hijau produk KTHR Rukun Amanah Desa Sukodadi Kecamatan Wagir Kabupaten Malang Jawa Timur dilakukan dengan beberapa tahapan pelaksanaan sebagai berikut:

\section{1) Persiapan}

a. Mengumpulkan data-data terkait KTHR Rukun Amanah, khususnya pada industri pengolahan cincau hijau di Desa Sukodadi Kecamatan Wagir Kabupaten Malang Jawa Timur. Hal tersebut dilaksanakan untuk mendapatkna data terkait masalah seperti apa yang membutuhkan solusi dan pendampingan yang tepat. Selain itu, melihat proses pengolahan industri cincau hijau secara langsung.

b. Menyusun program pengabdian masyarakat. Program ini disusun untuk disosialisasikan kepada anggota kelompok KTHR Rukun Amanah dan pemilik industri pengolahan cincau hijau. Program utama dari pengabdian adalah pembuatan kemasan baru dan pemasaran olahan cincau hijau.

c. Memformulasikan strategi pelaksanaan program secara bertahap serta menyiapkan peralatan yang dibutuhkan untuk pelaksanaan program pendampingan.

\section{2) Pelaksanaan}

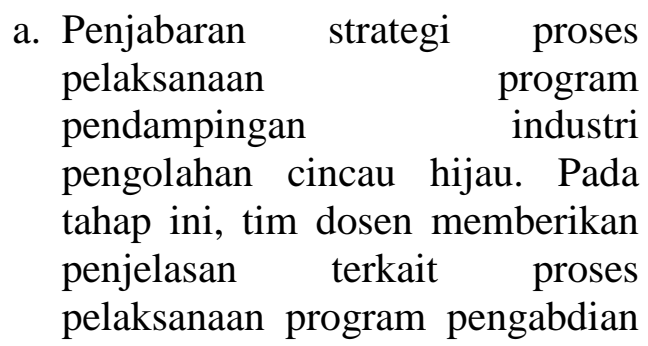


yang terdiri dari pendampingan pengemasan produk olahan minuman cincau hijau serta pendampingan pembuatan label merk untuk produk minuman tersebut.

b. Komunikasi dan kontribusi untuk mitra sasaran pengabdian masyarakat

c. Koordinasi progress pelaksanaan pendampingan kepada masyarakat.

\section{3) Monitoring dan Evaluasi}

a. Kegiatan monitoring dan evaluasi terhadap pelaksanaan program pengabdian masyarakat dilaksanakan setiap 2 minggu sekali dalam 6 (enam) bulan masa pengabdian dan pendampingan industri pengolahan cincau hijau di Desa Sukodadi Kecamatan Wagir Kabupaten Malang Jawa Timur.

b. Metode evaluasi menggunakan metode deskriptif yaitu penyelidikan mendalam di lapangan (field research). Metode ini digunakan untuk menggambarkan fenomenafenomena yang terjadi di tempat mitra pengabdian selama program pengabdian dilaksanakan.

\section{4) Pelaporan}

$\begin{aligned} & \text { Setelah program pengabdian } \\ & \text { masyarakat } \\ & \text { serangkaian kegiatan pengabdian } \\ & \text { dirangkum dalam satu laporan }\end{aligned}$
dilanakan,

\section{HASIL DAN PEMBAHASAN}

Berdasarkan hasil pelaksanaan kegiatan program pengabdian kepada masyarakat serta pendampingan industri pengolahan cincau hijau, dapat dijabarkan hasil dan luaran program serta dampaknya terhadap mitra selama proses pendampingan. Didapatkan bahwa mitra sasaran dapat menghasilakn inovasi berupa pembaharuan kemasan minuman cincau hijau yang awalnya menggunakan gelas plastik diganti dengan kemasan botol yang lebih menarik. Dampak yang sigifikan dapat dilihat dari segi penjualan yang naik setelah adanya inovasi kemasan tersebut.

Program pengabdian masyarakat ini memberikan dampak yang positif terhadap penjualan dari produk olahan minuman cincau hijau. Selama rentang waktu pendampingan selama kurang lebih 6 (enam) bulan, terdapat peningkatan permintaan terhadap produk minuman cincau hijau yang dihasilkan oleh KTHR Rukun Amanah. Perluasan pemasaran dilakukan dengan cara memasukkan produk minuman cincau hijau ke beberapa pedagang toko kelontong maupun pedagang minuman yang ada di sekitar Malang Raya.

Berikut adalah tahapan pelaksanaan program pengabdian masyarakat yang telah dilakukan:

\section{1) Persiapan}

Pada tahap ini, observasi atau studi lapang dilaksanakan langsung ke lokasi tempat mitra berada yaitu di Desa Sukodadi Kecamatan Wagir Kabupaten Malang. Berdasarkan hasil observasi, ditemukan permasalahan yang dihadapi oleh mitra, sebagai berikut:

a. Kemasan produk yang kurang menarik dan kurang memadai untuk dijual ke pasar yang lebih luas.

b. Produk cincau hijau belum mempunyai label merk yang menarik.

c. Keterbatasan pemasaran hasil produksi. Selama ini, mitra hanya menjual produknya di sekitar wilayah desa saja.

Berdasarkan permasalahan yang ada tersebut, maka tim pengabdi menawarkan beberapa solusi untuk 
memecahkan permasalahan yang ada pada industri pengolahan cincau hijau. Fokus solusi yang akan diberikan yaitu terkait aspek produksi, khususnya inovasi kemasandan aspek pemasaran produk.

Aspek produksi yang ditawarkan adalah pendampingan membuat logo merk yang menarik dan sesuai dengan produk yang ada. Selain itu, penggantian kemasan untuk minuman cincau hijau yang awalnya memakai plastik menjadi kemasan botol yang lebih menarik dan mudah dibawa kemana-mana.

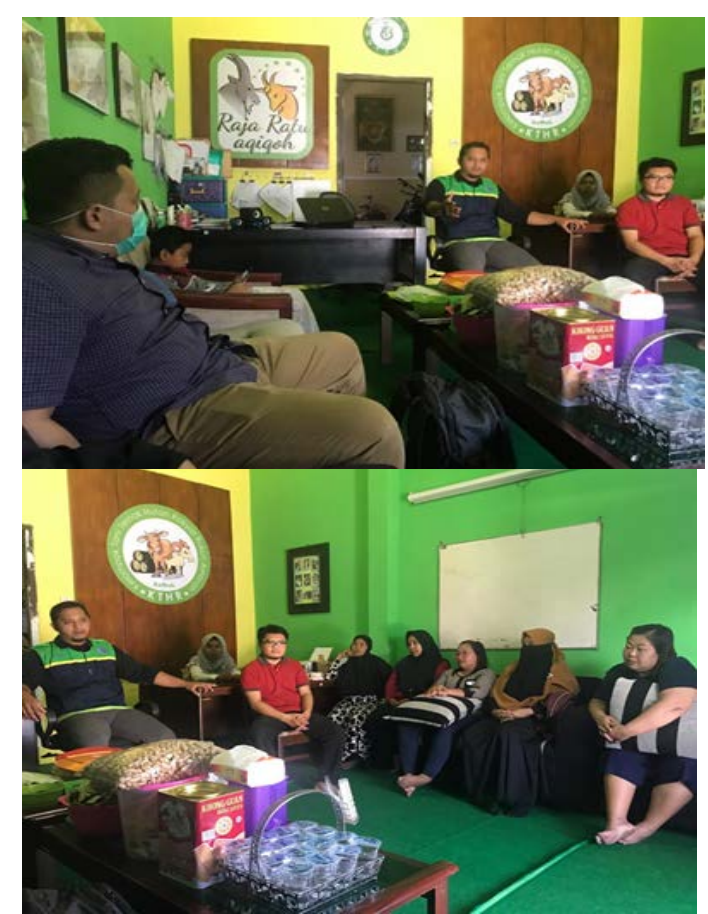

Gambar 1. Sosialisasi Program Pengabdian

Selain aspek produksi, aspek pemasaran yang ditawarkan berupa memperluas area pemasaran. Salah satunya adalah dengan menjual produk cincau hijau ini ke lapak yang ada di kampus FEB Universitas Muhammadiyah Malang.

\section{2) Pelaksanaan}

Pelaksanaan

program pengabdian dengan memberikan solusi terhadap permasalahan yang dihadapi oleh mitra difokuskan pada dua aspek yaitu aspek produksi dan aspek pemasaran. Tahapan pelaksanaan kegiatan ini adalah sebagai berikut:

a. Desain logo merk

Pendampingan pembuatan logo merk minuman cincau hijau dilaksanakan oleh tim dosen. Pembuatan logo merk ini bertujuan untuk memberikan daya tarik dan nilai jual bagi produk minuman cincau hijau. Sebelumnya, minuman cincau hijau yang dihasilkan oleh KTHR Rukun Amanah belum memiliki label merk tersendiri karena penjualannya hanya menggunakan plastik biasa. Untuk itu, tim dosen pengabdi memberikan solusi agar produk minuman cincau hijau ini dapat lebih menarik untuk dijual.

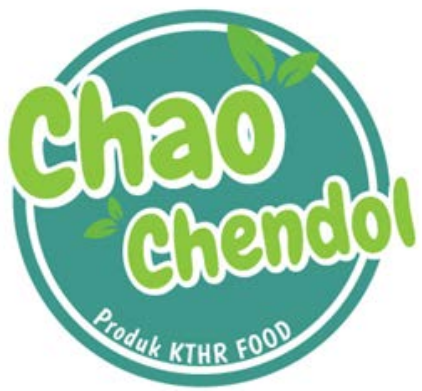

Gambar 2. Logo Merk Produk Minuman Cincau Hijau

b. Inovasi kemasan

Inovasi kemasan yang dipakai untuk produk minuman cincau hijau ini adalah berupa botol plastik yang bentuknya lebih menarik konsumen. Penggunaan botol plastik ini selain menambah daya tarik penjualan, juga dapat mempermudah pemasaran karena dapat dibawa kemana-mana tanpa khawatir tumpah. Pemilihan botol kemasan sendiri disesuaikan dengan tren yang ada di masyarakat. Kebanyakan, penggunaan botol plastik ini menjadi pilihan bagi produsen yang menjual minuman untuk menambah daya tarik penjualan produknya. 


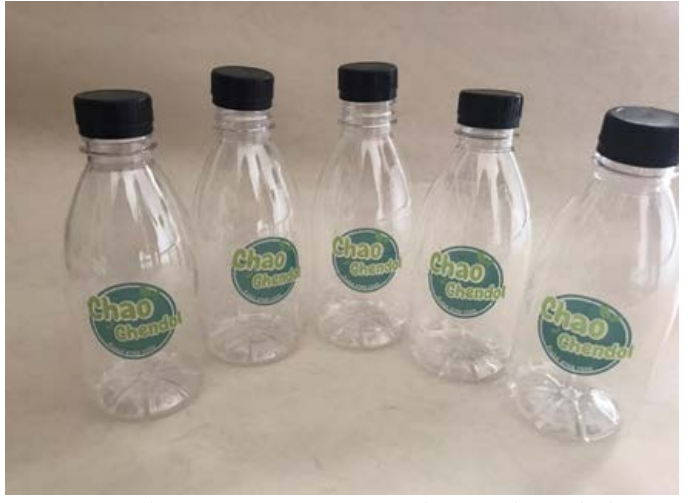

Gambar 3. Kemasan Chao Chendol

\section{c. Aspek Pemasaran}

Pengembangan pemasaran yang dilakukan dalam program pengabdian ini adalah dengan membantu menjual produk minuman Chao Chendol ke bazaar dan juga lapak yang ada di lingkungan kampus Universitas Muhammadiyah Malang.

\section{3) Tahap Evaluasi}

a. Evaluasi Pengembangan Usaha Mitra

Evaluasi ini dilihat dari keberhasilan program pengabdian yang telah dilaksanakan. Evaluasi dilaksanakan dalam dua aspek yaitu aspek produksi dan aspek pemasaran.

Aspek produksi dilihat dari keberhasilan mitra dalam mengadaptasi inovasi baru dalam perubahan kemasan serta adanya label merk yang menambah nilai jual produk minuman cincau hijau. Selain itu, label merk dan kemasan yang baru ini menambah tingkat kepercayaan diri mitra dalam memasarkan produknya. Mitra mulai percaya produknya dapat bersaing dengan produk minuman lain yang ada di pasaran.

Selanjutnya adalah evaluasi dari aspek pemasaran. Terdapat peningkatan penjualan setelah adanya perubahan inovasi kemasan untuk produk minuman cincau hijau. Minuman cincau hijau awalnya hanya dipasarkan di lingkungan sekitar KTHR, namun setelah adanya program pengabdian, penjualan minuman cincau hijau dapat menjangkau masyarakat yang lebih luas. Hal tersebut akhirnya meningkatkan penjualan produk minuman cincau hijau produksi KTHR Rukun Amanah.

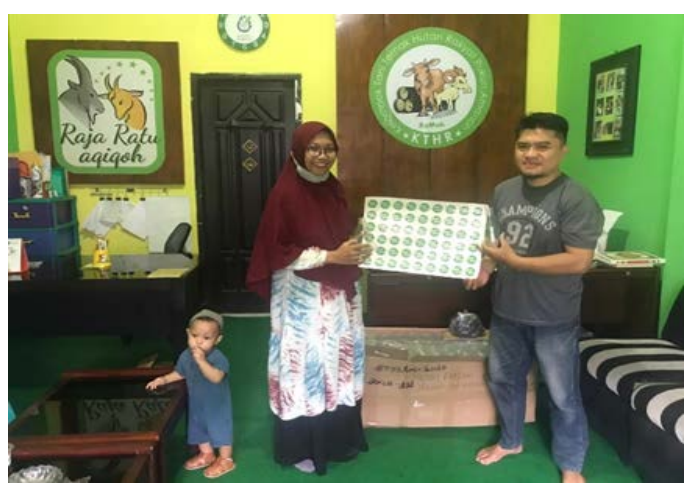

Gambar 4. Kunjungan Monitoring dan Evaluasi

b. Evaluasi Proses Kegiatan Pengabdian Pelaksanaan program pengabdian telah sesuai dengan rancangan kegiatan yang disusun. Menurut mitra, kegiaan pengabdian masyarakat in memberikan manfaat yang besar bagi mitra. Namun, dalam pelaksanaan kegiatan pengabdian tidak luput dari kendala yang ada. Berikut adalah kendala-kendala yang dihadapi selama program pengabdian:

(i) Kurangnya kepercayaan diri mitra untuk memasarkan produknya ke pasar modern.

(ii)Sulitnya mencari waktu untuk kegiatan sosialisasi program pengabdian

\section{4) Pelaporan}

Rangkaian kegiatan program pengabdian telah dilaporkan dan menghasilkan beberapa output diantaranya adalah artikel, poster kegiatan, dan brosur promosi.

\section{SIMPULAN}

Berdasarkan pelaksanaan program pengabdian masyarakat yang 
Happy Febrina Hariyani,dkk. Inovasi Kemasan Dan Peluasan Pemasaran Produk ...

dilakukan oleh tim dosen pengabdi dari Fakultas Ekonomi dan Bisnis Universitas Muhammadiyah Malang dengan program pendampingan KHTR Rukun Amanah khususnya pada industri pengolahan cincau hijau, didapatkan kesimpulan bahwa kegiatan ini memiliki manfaat yang besar dalam pengembangan pemasaran produk minuman cincau hijau. Rancangan strategi pengabdian yang telah disusun di awal program juga terlaksana sesuai dengan harapan.

Dari hasil evaluasi, didapatkan beberapa indicator perubahan yang diperoleh dari mitra, yaitu inovasi kemasan produk, adanya label merk yang tertera, yaitu "Chao Chendol" dan perluasan pemasaran minuman cincau hijau

\section{UCAPAN TERIMA KASIH}

Penulis mengucapkan terima kasih kepada Fakultas Ekonomi dan Bisnis Universitas Muhammadiyah Malang yang telah memberi dukungan dana terhadap kegiatan pengabdian ini.

\section{DAFTAR PUSTAKA}

Amaya, N., \& Alwang, J. (2011). Access to Information and Farmer's Market Choice: The Case of Potato in Highland Bolivia. Journal of Agriculture, Food Systems, and Community Development, 1(4), 35-53. https://doi.org/10.5304/jafscd.2 011.014 .003

Hasan, A. (2013). Marketing dan Kasus-Kasus Pilihan. Yogyakarta: CAPS.

Khamidah, N. (2005). ANALISIS PENGARUH FAKTOR LINGKUNGAN TERHADAP INOVASI PRODUK DAN KREATIVITAS STRATEGI
PEMASARAN TERHADAP

KINERJA PEMASARAN

(Studi pada Perusahaan kerajinan keramik di Sentra Industri Kasongan, Kabupaten bantu, Yogyakarta). In Jurnal Sains Pemasaran Indonesia (Vol. 4, Issue 3, pp. 231-246). https://doi.org/10.14710/jspi.v4 i3.231-246

Kotler, P. (2012). Prinsip-Pprinsip Pemasaran Edisi 13. Jakarta: Erlangga.

Lokesh, D., \& Amitsankar, D. (2012). Evaluation of mechanism for antihypertensive action of Clerodendrum colebrookianum Walp.; Used by folklore healers in north-east India. Journal of Ethnopharmacology, 143(1), 207-212. https://doi.org/10.1016/j.jep.20 12.06 .025

McDaniel. (2002). Entrepreneurship and Innovation: An Economic Approach. New York: ME Sharpe.

Nurdin, N., Kusharto, C. M., Tanziha, I., \& Januwati, M. (2009). KANDUNGAN KLOROFIL BERBAGAI JENIS DAUN TANAMAN DAN CuTURUNAN KLOROFIL SERTA KARAKTERISTIK FISIKO-KIMIANYA. Jurnal Gizi Dan Pangan, 4(1), 13. https://doi.org/10.25182/jgp.20 09.4.1.13-19

Nurlela, J. (2015). REVIEW : THE EFFECT OF LEAF GREEN GRASS JELLY EXTRACT (Cyclea L. barbata Miers) TO MOTILITY IN MICE BALB/C MALE THAT EXPOSED SMOKE. J Majority |, 4, 57-63. http://juke.kedokteran.unila.ac. 
id/index.php/majority/article/vi ewFile/579/583

Opan Arifudin, Fenny Damayanti Rusmana, Rahman Tanjung, \& Udin Wahrudin. (2020). Inovasi Kemasan Dan Perluasan Pemasaran Dodol Nanas Di Subang Jawa Barat. Dinamisia: Jurnal Pengabdian Kepada Masyarakat, 4(3), 408417.

https://doi.org/10.31849/dinam isia.v4i3.4469

Siregar, I. M., \& Miladiyah, I. (2011). Protective effects of Cyclea barbata Miers leaves against aspirin-induced gastric ulcer in mice. Universa Medicina, 30(2), 88-94.

Tambajong, G. (2013). Bauran Pemasaran Pengaruhnya Terhadap Penjualan Sepeda Motor Yamaha Di Pt. Sarana Niaga Megah Kerta Manado. Jurnal EMBA, 1(3), 12911301.

Widayati, R., \& Rahman, M. (2019). Aktivitas Pemasaran Produk Tabungan Pada Pt. Bpr Rangkiang Denai Payakumbuh Barat. 1-10. https://doi.org/10.31219/osf.io/ 3z7p6 